\title{
Future of forestry in Britain
}

\section{A government decision about the future of British forestry is expected shortly. John Gribbin reviews the possible development of forestry in Britain in the light of the recently published annual report of the Forestry Commission.}

THE future organisation of forestry activities in Britain has been under consideration now for several years.

The Committee of Public Accounts of Session 1967-68 expressed concern over the substantial losses of the Forestry Commission and the poor prospects for the future. It was at that time that there was a call for a proper consideration of whether the commission's noncommercial activities produced sufficient social benefits to justify the heavy expenditure. So the feeling at government level of a need for a complete overhaul of the Forestry Commission can certainly be traced back six years, and the overall review of forestry in general stems from this careful look at the Forestry Commission.

A White Paper published in June 1972 outlined the direction in which the government saw forestry developing, and recognised the need for landscape improvement and maintaining the character of traditional hardwood areas. But in itself that review had little practical effect, although at about the same time smallwood planting grants were suspended and replaced by an interim grant scheme to bridge the gap until a new structure had been worked out.

By October $1973 \mathrm{Mr}$ Anthony Stodart, the then Minister of State at the Ministry of Agriculture, Fisheries and Food (MAFF), was able to report to the Commons that a general framework for the future of forestry policy had been worked out, and details were then expected to be announced early in 1974. But the General Election and resulting change of government has delayed announcement of a detailed policy; in the House of Commons on April $11 \mathrm{Mr}$ Stodart asked Mr Roland Boyle, the Secretary of State at MAFF who now has responsibility for forestry, whether a decision had now been reached, and was told that "consultations are still in progress". Pressed by a Member concerned that woodland owners had no idea what to do about the 1974-75 planting programme because the decision had not been taken, Mr Boyle replied "we have the matter very much in mind and hope to be able to announce a decision as soon as possible". Since then, the Forestry Commission Annual Report and Accounts 1972-73 has been published (HMSO, 90p); together with previous government statements this makes it possible to foresee the likely development of forestry in Britain once the awaited government decision is announced.

One key change which has already been made is a reconstruction of the commission's accounts. From 1919 to 1972 the accounts have had to bear interest charges at the appropriate government lending rates, and these have averaged about $5 \%$ compounded over that period. Under the new structure the aim is to be a rate of return on funds of $3 \%$, which is accepted as the maximum that forestry can be expected to earn in northern Europe on the best sites close to markets. That is an important proviso, for much of the commission's planting has been undertaken for strategic or social reasons, and cannot be expected to provide such a high return. "Where less profitable activities are undertaken for reasons of government policy", says the report, "the commission will be given ... subsidies each year to bridge the gap between $3 \%$ and the expected rate of return".

This policy is not affected by Britain's entry into the European Economic Community (EEC), which has no common forestry policy. Regulations to implement two EEC directives concerning improvement of genetic and other standards of seeds, young plants and so on became effective on July 1, 1973, and the EEC Commission is considering a draft directive which, although chiefly devoted to improving the structure of agricultural holdings, has some implications for forestry. But otherwise the British government has essentially a free hand in forestry matters.

It must be remembered, of course, that only half of the total productive forest area in Britain is owned by the commission; but in practice the interests of private and state forestry are complementary and cooperative, rather than competitive. A major difference

Table 1 Land use by Forestry Commission at March 31, 1973 (Thousands of hectares*)

\begin{tabular}{lrrrr} 
& Great & & & \\
& Britain & England & Scotland & Wales \\
Total area & $1,212.0$ & 306.7 & 744.6 & 160.7 \\
Forest Land: Total & 882.1 & 261.7 & 481.9 & 138.5 \\
Under plantations & 768.3 & 239.5 & 399.5 & 129.3 \\
To be planted & 113.8 & 22.2 & 82.4 & 9.2 \\
$\begin{array}{l}\text { Other Land: Total } \\
\quad \text { Nurseries }\end{array}$ & 329.9 & 45.0 & 262.7 & 22.2 \\
$\begin{array}{l}\text { Agricultural and } \\
\text { grazing }\end{array}$ & 0.3 & 0.1 & 0.2 & - \\
$\begin{array}{l}\text { Forest Workers } \\
\quad \text { Holdings }\end{array}$ & 151.5 & 14.2 & 123.2 & 14.1 \\
$\quad \begin{array}{l}\text { Unplantable and } \\
\quad \text { miscellaneous }\end{array}$ & 5.1 & 1.1 & 2.9 & 1.1 \\
\hline
\end{tabular}

* 1 hectare $=2.471$ acres

Table 2 Planting in the year ended March 31, 1973 (hectares)

\begin{tabular}{lrcc}
\hline & Total & New planting & Restocking \\
\hline Great Britain & 23,158 & 19,378 & 3,780 \\
$\quad$ Conifer & 22,865 & 19,224 & 3,641 \\
$\quad$ Broadleaved & 293 & 154 & 139 \\
England & 3,154 & 1,735 & 1,419 \\
$\quad$ Conifer & 2,890 & 1,608 & 1,282 \\
$\quad$ Broadleaved & 264 & 127 & 137 \\
Scotland & 17,764 & 16,174 & 1,590 \\
$\quad$ Conifer & 17,739 & 16,151 & 1,588 \\
$\quad$ Broadleaved & 25 & 23 & 2 \\
Wales & 2,240 & 1,469 & 771 \\
Conifer & 2,236 & 1,465 & 771 \\
Broadleaved & 4 & 4 & - \\
\hline
\end{tabular}

Conifers continue to dominate planting by the Forestry Commission, but that pattern is likely to be changed when details of the new government policy are announced. 
Peeled woodwool billets stacked for air-seasoning in a clearing of 47-year-old Scots Pine at Bramshill Forest, Camberley.

is that private forests are concentrated on 'traditional' areas whereas the commission has afforested wide areas formerly in marginal agricultural use. The Forestry Committee of Great Britain, which represents private forestry in discussions with the government, generally sees eye to eye with the Forestry Commission, although it is in a better position to speak out against government proposals even to the extent of commissioning its own investigation of the accuracy of government studies relating to forestry. Of course, the two sectors of the forestry industry are in a competitive situation in the 'market place', but that market is so hungry for timber that both sectors are assured of selling their product.

Where the private sector differs from the Forestry Commission, however, is that small planters are in a much more vulnerable position when there is an air of uncertainty about the future direction the industry is expected to take. This is highlighted by the fact that the interim scheme for smallwood planting grants has now run its course, and that since the beginning of this year there has been nothing to replace it. A spokesman for the Forestry Committee said last week that small owners are already being affected, and that "some nurseries are finding it very tough" as a result.

This is a matter of more immediate urgency than the question of what should be planted in the 1974-75 season. For the private sector, the 197374 planting season is essentially over, and although there is a clear need for plans for the next season to be put in hand as soon as possible, there is probably less urgency about this at present than at any other time of the year. Of course, there can be little doubt that the detailed government plans will include a hardwood planting supplement - but it is up to the individual owner or planter to decide whether this is attractive enough for him to change his pattern of planting. All this takes time, and the present situation of uncertainty is clearly undesirable.

But the most important fact which must be taken into account when the government announces its new detailed plans is that in forestry terms Britain is very nearly saturated, with about $8 \%$ of the country covered by forest. Most of the figures in Table 1 are slightly down on last year; on March

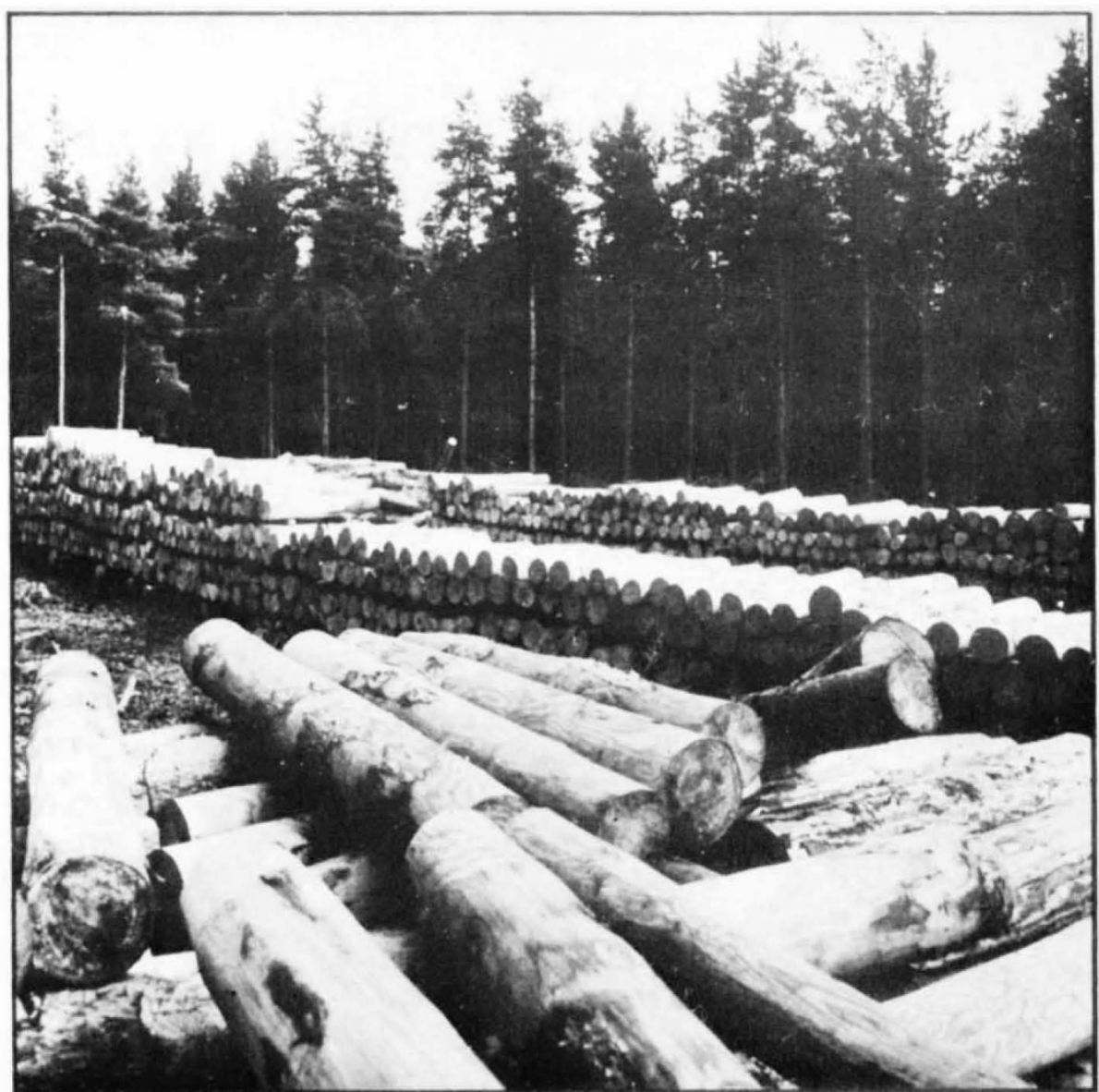

31, 1972, for example the corresponding figures for forest land and total area were 876.2 and $1,215.0$ thousand hectares, respectively. The total area of forest land acquired in the year ended March 31, 1973 was 6,000 hectaresmore than 10,000 hectares less than in the previous year, and some 15,000 hectares less than in 1971 72. One reason for this is improvements in the sheep farming industry which make less land available for forestry; by and large, there is no longer any suitable land on the market.

In the light of this, and the removal of forestry's strategic role, the future emphasis is likely to be on forestry

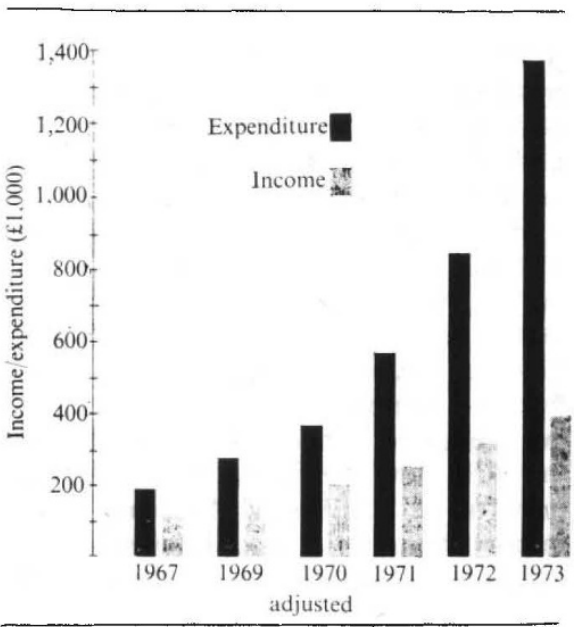

for amenity use. More hardwoods are likely to be planted than conifers, and existing forests will be promoted as recreational facilities. Indeed, the latter is already happening in a dramatic way.

The commission has also been involved in "plant a tree in ' 73 " activities, including reclamation of 2 hectares of a derelict iron ore site in Cumberland, 6 hectares of coal tip at Kilsyth in Stirlingshire, and 12 hectares of derelict mining valley at Aberdare, Glamorgan.

It is perhaps ironic that these changes should be coming about at a time when world market conditions have caused a dramatic increase in softwood prices; demand for home grown sawlogs almost doubled in the last quarter of the year covered by the report and there is, according to the report, a "strong desire" among British woodusing industries to use the dependable home grown product wherever possible. But with Recreation Planning Officers appointed in most conservancies, a feasibility study underway investigating development of low cost tourist accommodation on commission land, and the general restructuring of the commission's activities the future of forestry in Britain is clearly going to be markedly different from its immediate past. It seems appropriate that the commission is making a move to a new headquarters, near Edinburgh, at this time; it will be installed there by the middle of 1975 . 